\title{
Policy Networks in Improving the Quality of Housing and Settlements in Indonesia (A Case Research of Bandung District)
}

\author{
Riki Satia Muharam ${ }^{1}$, Ono Taryono ${ }^{2}$, Lidia Maasir ${ }^{3}$, Siti Widharetno $\mathrm{M}^{4}$ \\ ${ }^{1}$ Doctoral Candidate in Public Administration, Faculty of Social and Political Science, Universitas Padjadjaran, Indonesia \\ 2,3,4 Politeknik STIA LAN Bandung, Indonesia
}

\begin{abstract}
Studies on slum housing and settlements have been carried out in many countries. The various studies show that the problem of housing and settlement areas can no longer be considered a simple problem. Different from the various studies on housing and settlement areas, this research employs the perspective of policy networks as a new public administration paradigm. The development issue on housing and settlement areas is regarded as one of the contemporary international issues contained in one of the 17 Sustainable Development Goals (SDGs). Several countries have become the focus of attention, such as: India, Mongolia, Sri Lanka, Pakistan, and Thailand. In Indonesia, the development of housing and settlement areas is mandated by law. The Local Government of Bandung District has made efforts to improve the quality of housing and settlements through such programs as the PLPBK, Rutilahu, and Kotaku. However, the improvement in the quality of housing and settlements in general has not touched the basic problem, namely the welfare of the community. The development is limited to physical improvements and lasts 1 (one) to 2 (two) years. In the third year the restored area becomes irregular / slum again. Therefore, it is recommended that the Bandung District government issue a local regulation in the form of a Regent Regulation concerning the improvement of housing and settlement quality and a plan for handling it as the legal bases. In addition, a collaboration of actors in policy networks should be formed based on the pentahelix model incorporating the actors of business, government, community, academic, and media.
\end{abstract}

\section{CONTACT}

riki.satiam@gmail.com

\section{KEYWORDS}

Policy Networks, Housing, Settlement, Indonesia

\section{INTRODUCTION}

Studies on housing and slum settlements have been carried out in many countries such as India, Mongolia, Srilanka, Pakistan, Thailand including Indonesia (Akbar \& Alfian 2018; Paul Jones, 2016; Wijaya, 2016; Nursyahbani \& Pigawati, 2015; Fitria \& Setiawan, 2014). Akbar \& Alfian (2018) reveals that the influence of thematic village development in an effort to overcome urban development problems in Malang City has a very positive impact in handling the development of Malang City area. Paul Jones (2016) states that the way city governments manage slum areas by trying to reshape and restructure people's lifestyles has a big impact. Wijaya (2016) declares that there are eleven classifications of slum areas and five priority areas for improving the quality of infrastructure in slum areas. Nursyahbani \& Pigawati (2015) remark that the characteristics of slum settlements are known from the characteristics of the occupants, the characteristics of the occupancy, the characteristics of the infrastructure, and the characteristics of the environment. In line with Nursyahbani \& Pigawati, Fitria \& Setiawan (2014) mention the characteristics of slum areas based on 5 aspects, namely physical circumstance, economic condition, availability of facilities and infrastructure, social condition, and hazards.

The various studies above show that the problem of housing and settlement areas can no longer be considered a simple problem. Different from the various studies on housing and settlement areas, this research employs the perspective of policy networks as a new public administration paradigm. It is believed that the involvement of many actors in the implementation of public affairs is considered important. States and governments in the global era no longer represent the only institutions or actors efficiently, economically, and fairly capable of providing various forms of public service. Partnerships (partnerships) and networks (networking) among various stakeholders also play important roles in the implementation of public affairs (Denhardt \& Denhardt, 2007; Robinson, 2015).

The development issue on housing and settlement areas is regarded as one of the contemporary international issues contained in one of the 17 Sustainable Development Goals (SDGs), namely goal 11: make cities and human settlements inclusive, safe, resilient and sustainable. Several countries have become the focus of attention, 
such as: India, Mongolia, Sri Lanka, Pakistan, and Thailand. Housing development policy in India is prioritized in urban areas. Efforts are made to address the shortage of housing for the poor through the strategy of launching a special mission for the National Jawaharlal Nehru Urban Renewal. The Mongolian Parliament issues approval of the " 40,000 Houses" program. The aim of the program is to increase the number of national housings and the amount of finance for housing. Since 1970, the Government of Sri Lanka has regularly implemented a public housing program. The housing program is carried out through a community participation approach. The Pakistani government has launched various programs to meet the housing needs of low-income groups and government employees. The Thai government has two important agencies in charge of housing, namely the National Housing Authority (NHA) with the Baan Eua-Arthorn Program (BEA) and the Community Organization Development Institute (CODI) with the Baan Man Kong Program (BMK). BEA is a new community housing program that allows low-income households to own homes in new a community either communally or individually. The concept of BMK is not to solve slum housing problems individually but to look at collective problems on a larger scale.

In Indonesia, the development of housing and settlement areas is mandated by law. In the amendment of the 1945 Constitution Article $28 \mathrm{H}$, paragraph 1, it is stated that the house is one of the basic rights of the people. Therefore, every citizen has the right to get a good and healthy place and environment to live. According to the Law No.1 of 2011 concerning Housing and Settlement Areas, every Indonesian citizen has the right to live in physical and mental well-being, have a place to live and have a good and healthy living environment. Article 5 of Law No.1 of 2011 states that the State is responsible for the provision of Housing and Settlement Areas (PKP) in accordance with their respective duties and authorities. In implementation, it is carried out by the central government, provincial governments, and district / city governments. Article 6 paragraph (1) more explicitly explains the role of development by the provincial government including planning, regulation, control, and supervision. Whereas the Article 15 mentions sixteen duties and authorities of district / city governments regarding PKP. In point (a) of article 15 it is explained that the district / city government is in charge of formulating and determining policies and strategies at the provincial level in the field of housing and settlement areas based on the national and provincial policies and strategies. Thus, the district / city government has the authority to achieve these targets by means of collaboration.

With a geographical condition dominated by hills and mountains, Bandung District is vulnerable to social problems, one of which is slum areas. The area on the banks of the Citarum river is considered the most slum area. There are 30 spots of slum area in Bandung District with an area of 91.83 hectares. The slum areas are located in 16 of 31 sub-districts throughout Bandung District. Out of 30 spots, Baleendah Village has the largest slum area covering 17.65 hectares. This research examines the Policy Networks which are effective in improving the quality of housing and settlement in Bandung District.

\section{METHODS}

This research employed a qualitative method trying to reveal the problem in improving the quality of housing and settlement in Bandung District. The qualitative method emphasizing the epistemological method in this research is expected to be able to reformulate and reconceptualize the improvement of the quality of housing and settlements from the perspective of the Policy Network. Judging from the ontology, the research discusses what one wants to know from events where the improvement in the quality of housing and settlement has not matched the expectation in the process or the results. Viewed from the axiology, this research is expected to positively contribute to the development of public administration science as well as the efforts to improve the quality of housing and settlement in Bandung District in particular and other local governments in general. Thus, the use of qualitative method is relevant with the problem, aim and objective of this research.

Sources of data in this research were divided into two parts, secondary data, and primary data. The secondary data included the regulations and their derivative regulations, documents, photos, archives, journals, scientific papers, and statistical data related to the improvement of the quality of housing and settlement areas in Bandung District. These collected data were interpreted to be qualitatively meaningful. They consisted of: Law Documents, Presidential Regulations, Government Regulations, Ministerial Regulations, Local Regulations and the Regent Regulations of Bandung District, and other important texts as references to describe the improvement of housing and area quality settlements in Bandung District. Meanwhile, the primary data were obtained from research by the researchers in the field. Along with the qualitative method, the data were also collected by using the qualitative method.

In-depth interviews based on the interview guide were carried out face-to-face to the informants (according to their fields and duties) regarding the main issues in improving the quality of housing and settlement areas. The researchers observed the objects of research by conducting direct observations into the field to see the condition 
of the housing and settlement quality in Bandung District in the framework of analysis. The researchers recorded the informants' information and conducted interviews with key informants by using cameras, audio recording devices, and writing instruments, so that the research was more focused and kept track to the researchers' expectations.

The data analysis was performed by open coding and axial coding. Open coding is the process of reading data from the interview results, labelling some of the data that have meanings, and categorizing the meaningful data based on the labels given. While axial coding is the process of identifying relationships between categories that have been labelled at the open coding stage. From this identification, conclusion can be obtained (Charmaz, 2006). In this stage, the researcher carried out several stages, namely making interview transcripts, coding data, and making data categories according to the theme. The data were arranged in the form of a data finding matrix for analysis.

\section{RESULT AND DISCUSSIONS}

Geographically, Bandung District is located at 107o 22 '- 108o 50' East Longitude and 6o 41 '- 7o 19' South Latitude. From an administrative perspective, Bandung District is part of the administrative area of West Java Province. The administrative area of Bandung District covers 31 districts, 270 villages and 10 sub-districts with a total area of $176,238.67$ hectares.

The Local Government of Bandung District has made efforts to improve the quality of housing and settlements including the PLPBK, Rutilahu, and Kotaku programs. The Community-based Settlement Environment Management Program (PLPBK) or Neighbourhood Development is a follow-up intervention within the framework of the PNPM Mandiri Urban intervention strategy to build the transformation of an independent society towards civilization. This program aims to enable all people to live in harmony in a healthy environment, in an orderly, sustainable manner. The City Without Slum Program (Kotaku) is one of some strategic efforts to accelerate the handling of slums and supports the "100-0-100 Movement", namely 100 percent universal access to drinking water, 0 percent slum areas, and 100 percent access to proper sanitation. The Kotaku program addresses slums by building a collaborative platform through increasing the role of local government and community participation. The routine housing repair (Rutilahu) program for underprivileged families is community-based, meaning that it uses an environmental development approach involving the community as the main actor. The Rutilahu program can reduce the number of improper houses in Bandung District and motivate people to be self-sufficient and work together in realizing the homes that are livable, healthy, comfortable and in an orderly environment. Bumdes becomes the channel for the budget to the beneficiaries of the Rutilahu Program. The locus and implementation of activities carried out by the Bandung District Government in improving the quality of housing and settlements is depicted in Figure 1. as follows:

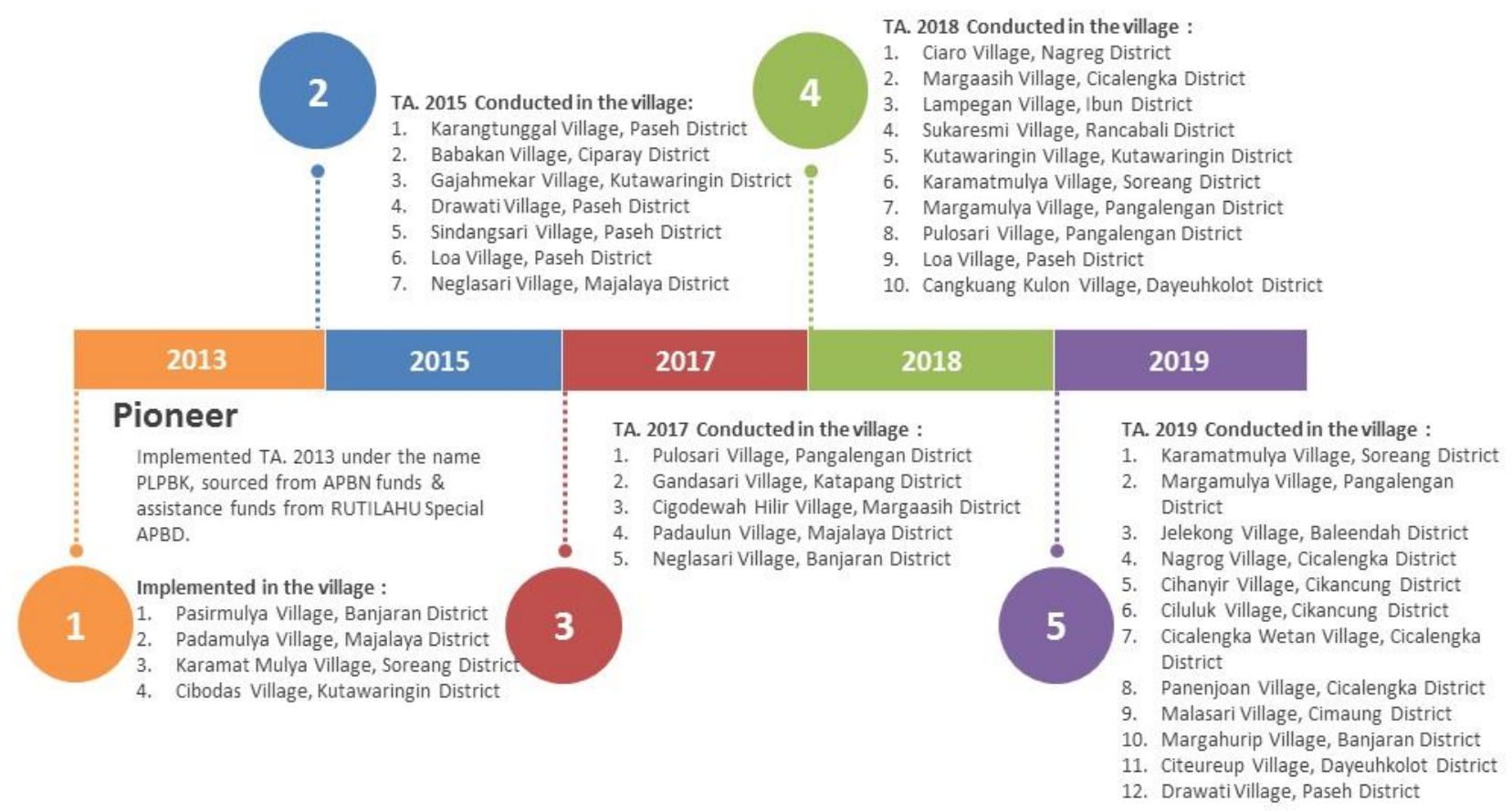

Figure 1. Implementation and Locations of Housing and Settlement Quality Improvement in Bandung District Source: Disperkimtan, 2021. 
Despite its implementation, improving the quality of housing and settlements in Bandung District has not matched the expectations, both the process and the results. It has not been implemented in accordance with the direction of integrated and sustainable settlement development referring to the Article 55 of Government Regulation No. 14 of 2016 concerning the implementation of housing and settlement development. The implementation of housing and settlement quality improvement in Bandung District in general has not touched the basic problem, i.e. the welfare of the community. The development is limited to physical improvements and lasts 1 (one) to 2 (two) years, in the third year the area becomes irregular / slum again. The families with a low economic level do not have the ability to maintain and care for the housing and settlement they occupy. This situation can be seen in some areas such as Jelekong Village, Baleendah District. It is an painters' village. The maintenance of the art village uniqueness is managed by the members of the community. Each painter tries to manage their own houses without being able to improve their environment. Jelekong Village has the potential to become a tourist destination as a painters' settlement.

Pasirmulya Village (Figure 2.) has also the PLPBK Program. It administratively belongs to the area of Banjaran Subdistrict. In the north it is bordered with Sindangpanon Village, Ciapus; Mekarjaya Village in the east, and Campakamulya Village in the south. Pasirmulya Village covers an area of $442 \mathrm{ha}$. The distance of Pasirmulya village from the district capital is $16 \mathrm{~km}$. The result of PLPBK activities includes the reconstruction of 31 uninhabitable houses, retaining walls with a volume of 1277 meters, neighbourhood roads with a volume of 666 meters, drainage with a volume of 992 meters, water piping with a volume of 1100 meters, Preschool building (PAUD) as much as 1 unit and Community Sanitation Facility (MCK) 3 units. In Pulosari Village, especially in Cibuluh Village, there have been arrangements ranging from road infrastructure, electricity networks, repairs to houses that are unfit for habitation, infrastructure and transportation improvements. Cibuluh village is expected to have tourism potential because it is connected to Situ Cileunca - a lake. In addition to the natural rural atmosphere, Cibuluh village is equipped with homestay; however, this has not been able to be carried out as expected.

The policy network in improving the quality of housing and settlement areas in Bandung District has not supported the achievement of the goals, due to the lack of integrated
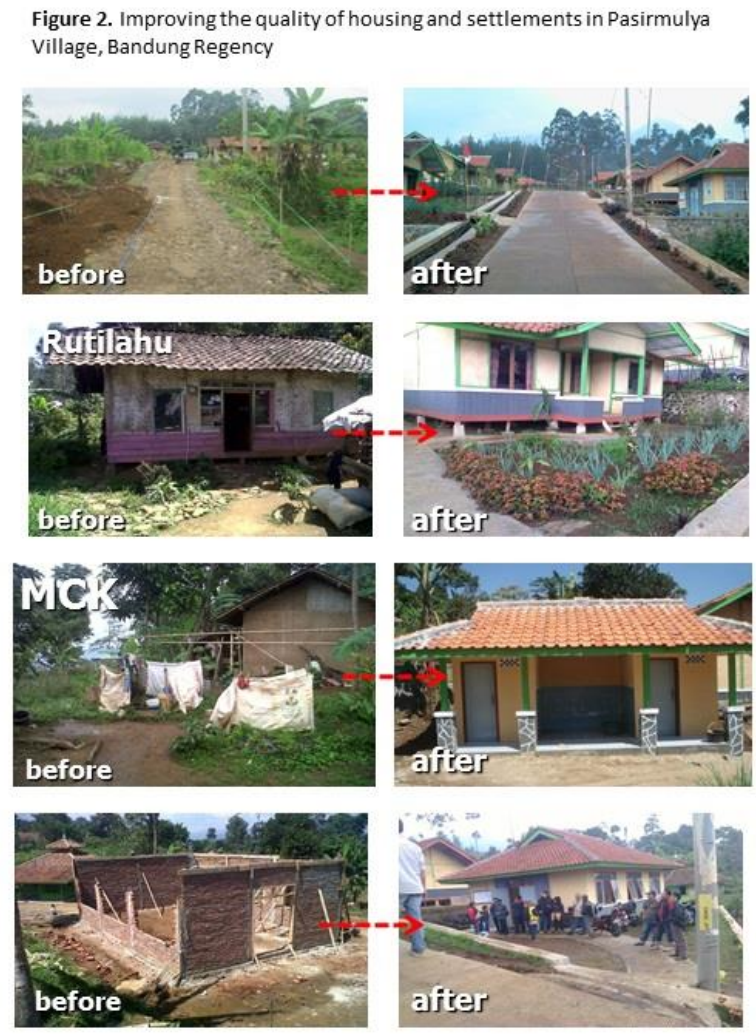

Source : Disperkimtan of Bandung Regency, 2021 roles and institutionalization among stakeholders. For example, the Bandung District Government has three Working Groups (Pokja) engaged in the housing sector: Pokja AMPL (Drinking Water and Environmental Health), Pokja Sanitasi, and Pokja PKP (Housing and Settlement Areas). However, in terms of planning, there has not been a single synchronized and comprehensive plan. Furthermore, the work mechanism which includes the division of roles, tasks and authorities has not evolved yet. This can be seen in two ways: first, in terms of data, there is no synchronous data from each stakeholder, and second, in terms of financing, the financing is so complex and the existence of numerous problems in achieving targets has an significant impact on financing. The involvement of other stakeholders is very important in financing, namely the private sector. In line with Etzkowitz's theory, networking involves: 1) Business, 2) Government, 3) Community, 4) Academic, and 5) Media. The role of government in this case is still too dominant, while the role of society and academics is less visible. In other words, the policy network that has been built has not been effective in achieving the goals and objectives. Whereas based on previous research, an effective policy network plays an important role in achieving the goals of a program that involves many actors.

The lack of integration between existing institutions is due to the absence of a clear legal umbrella related to the housing and settlement quality improvement, especially the handling of the problem of slum settlements. Thus, it is necessary to have a Local Regulation in relation with the prevention and quality improvement of slum settlements in the form of a Regent Regulation concerning Slum Management Plans for handling slum areas. Due to the lack of integrated institutions, work mechanisms and relevant stakeholder involvement as well as insufficient integrity, it is difficult to build a network model in improving the welfare of the community. 
Therefore, collaboration of actors in policy networks based on the pentahelix model (Business, Government, Community, Academic, and Media) is necessary to raise the quality of housing and settlements in Bandung District.

\section{CONCLUSIONS}

The Local Government of Bandung District has made efforts to improve the quality of housing and settlements through the PLPBK, Rutilahu, and Kotaku programs. The policy network that has been built has not been effective in achieving the goals and targets in improving the quality of housing and settlements. This can be seen from the fact that the roles and institutionalizations are not yet integrated among stakeholders. There is no synchronized and comprehensive planning. The work mechanism which includes the division of roles, tasks and authorities has not evolved yet. The role of the government in this case is still too dominant, while the role of the community and other stakeholders is less visible. An effective policy network plays an important role in achieving the objectives of the program that involves many actors.

Based on the research result, it is recommended that that the Bandung District government issue a local regulation in the form of a Regent Regulation concerning the improvement of housing and settlement quality and a plan for handling it as the legal bases. In addition, a collaboration of actors in policy networks should be formed based on the pentahelix model incorporating the actors of business, government, community, academic, and media.

\section{ACKNOWLEGDEMENTS}

We gratefully acknowledge funding support from the Hibah 'Penelitian Terapan Unggulan' in 2021 Politeknik STIA LAN BANDUNG.

\section{REFERENCES}

1. Adam Douglas Henry. 2011. "Ideology, Power, and the Structure of Policy Networks". The Policy Studies Journal, Vol. 39, No. 3.

2. Akbar, Taufik \& Alfian, Faqih. 2018. "Kampung Tematik sebagai bentuk Partisipasi Masyarakat dalam permasalahan permukiman kumuh di Kota Malang". Jurnal Wahana, Vol. 70 No. 2.

3. Alex, Dody Reza. 2019. "Jejaring Kebijakan dalam Pengelolaan Kawasan Ekonomi Khusus (KEK) (Studi Kasus di Kawasan Ekonomi Khusus Tanjung Api-Api Provinsi Sumatera Selatan)".

4. Bevir, Mark. 2011. Managing Networks: Propositions on What Managers Do and Why They Do It. Public Administration Review.

5. Carlsson, Lars. 2000. Policy Network as Collective Action, Policy Studies Journal, Vol. 28, No. 3.

6. Charmaz, K. (2006). Constructing Grounded Theory: A Practical Guide Through Qualitative Analysis. London: Sage.

7. Christiawan, Elisa Septiani. 2019. "Nilai Publik Program Rehabilitasi Sosial Rumah Tidak Layak Huni di Kota Surabaya".

8. Creswell, J. W. (2014). Research Design: Qualitative, Quantitative, and Mixed Methods Approaches, Fourth Edition. California: SAGE Publications.

9. Denhardt, J. V., \& Denhardt, R. B. (2007). The New Public Service: Serving, Not Steering. New York: M. E. Sharpe.

10. Denhardt, R. B., Denhardt, J. V., \& Blanc, T. A. (2014). Public Administration: An Action Orientation. Boston: Wadsworth.

11. Enroth, Johannes. 2010. The Multisectoral Trilemma of Network Management. Journal of Public Administration Research and Theory.

12. Erik-Hans Klijn \& Joop F.M. Koppenjan. 2000. "Public Management and Policy Networks : The Theoretical Foundation of the Network Approach to Governance". Jurnal Public Management, 2000 (2) nr 2, pp. $135-158$.

13. Fitria, Niken \& Setiawan, Rulli Pratiwi. 2014. "Identifikasi Karakteristik Lingkungan Permukiman Kumuh di Kelurahan Kapuk, Jakarta Barat". Jurnal Teknik Pomits Vol. 3, No. 2.

14. Hanspeter Kriesi, Silke Adam \& Margit Jochum. 2007. "Comparative analysis of policy networks in Western Europe". Journal of European Public Policy, 13:3, 341 - 361.

15. Hyun Hee Park, R. Karl Rethemeyer. 2014. "The Politics of Connections: Assessing the Determinants of Social Structure in Policy Networks"

16. Kickert, Klijn and Koppenjan. 1999. Managing Networks is The Public Sector: Findings and Reflections. London: Sage. 
17. Marsh, David and Rhodes, R.A.W. 1992. Policy Communities and Issue Networks: Beuond Typology, In David Marsh and R.A.W Rhodes (eds). Policy Networks in British Government. Oxford: Clarendon Press.

18. Nursyahbani \& Pigawati. 2015. "Kajian Karakteristik Kawasan Pemukiman Kumuh di Kampung Kota (Studi Kasus : Kampung Gandekan Semarang”. Jurnal Teknik PWK Volume 4 Nomor 2.

19. Peraturan Pemerintah Nomor 14 Tahun 2016 tentang penyelenggaraan perumahan dan kawasan permukiman

20. Perkin, Emily and Court, Julius. 2005. Networks and Policy Processes in International Development: a literature review. London, UK: Overseas Development Institute.

21. Rhodes, Rod. 2006. Under Standing Governance: Policy Networks, Governance, Reflexivity and Accountability. Buckingham, UK: Open University Press.

22. Rodriguez, Charo, Langley, Ann, Beland, Francois and Denis, Jean-Louis. 2007. Governance, Power and Mandated Collaboration in an Interorganizational Network. Administration and Society 39.

23. Roebyantho, Haryati. 2014. "Implementasi Kebijakan Penanggulangan Kemiskinan melalui Program Rehabilitasi Sosial Rumah Tidak Layak Huni (RLTH), di Kota Garut, Provinsi Jawa Barat". SOSIO KONSEPSIA Vol. 4, No. 1, September - Desember.

24. Sabatier, Paul A. 1993. Policy Change and Learning: An Advocacy Coalition Appoach. Westview Press. Boulder Co.

25. Sawitri, Sri. 2011. Jejaring Kebijakan Publik: Kerangka Baru Penyelenggaraan Pemerintahan. Purwokerto: Universitas Diponogoro.

26. Suparwoko. 2013. "Peningkatan Kapasitas Perumahan Swadaya di Indonesia". Penerbit : Total Media.

27. Undang-Undang No 23 tahun 2014 tentang Pemerintahan Daerah.

28. Undang-Undang Nomor 1 Tahun 2011 tentang Pembangunan Perumahan dan Kawasan Permukiman.

29. Vangen, Siv \& Huxham, Chris. "Introduction the theory of collaborative advantage". In Osborne, S., (Ed.). 2010. "The New Public Governance ? Emerging perspectives on the theory and practice of public governance. Routledge, pp. 163-184.

30. Waarden, Frans Van. 1992. "Dimensions and types of Policy Networks". European Journal of Political Research $21: 29-52$.

31. Wijaya, Donny Wahyu. 2016. "Perencanaan penanganan kawasan permukiman kumuh studi penentuan kawasan prioritas untuk peningkatan kualitas infrastruktur pada kawasan pemukiman kumuh di Kota Malang”. Jurnal Ilmiah Administrasi Publik (JIAP) Vol. 2, No. 1, pp 1-10. 